\title{
Evaluation of genotoxic and cytotoxic effects of Glyphosate on Allium cepa
}

\author{
Yousif M. Fattah ${ }^{1 *}, 2$ Ali H. Omer \\ ${ }^{1}$ Dept. of Biology, Faculty of Science, University of Zakho, Zakho, Kurdistan Region, Iraq \\ ${ }^{2}$ Dept. of Biology, Faculty of Science, University of Zakho, Zakho, Kurdistan Region, Iraq \\ *Corresponding author: ali.artoshi90@gmail.com
}

\begin{abstract}
.
Glyphosate is a broad-spectrum herbicide used mostly in crops. This study looked at the genotoxic and Glyphosate has a cytotoxic effect on Allium cepa. As toxicity markers, the Mitotic index, chromosomal aberrations, formations of Micronucleus, germination percentage, root duration, and seed weight were used. Allium cepa seeds were afflicted with distinct concentrations $(0.5,1.0,2.0$ and $4.0 \mathrm{ml} / \mathrm{l}$ ) of Glyphosate for $24 \mathrm{~h}$ treatment periods. The results reveal that pesticide Glyphosate is capable to reduce root growth and causes chromosomal aberrations; consisting of an anaphase bridge, ring chromosome, binucleated cells, multipolarity, Fragment chromosome, vagrant chromosome, chromatid gaps, star anaphase. With increasing Glyphosate concentration, the mitotic index decreased rapidly. In conclusion, our findings indicate that used pesticide may be toxic to living organism.
\end{abstract}

Keywords: Allium cepa, Glyphosate, chromosomal aberrations, Mitotic index.

\section{Introduction}

Pesticides are chemical agents that have been created to protect crops and prevent disease in humans by eliminating pests such as rats, rats, plants, fungi, and plant disease. In order to destroy or disable the insect, they normally work by interrupting some components of the pest's life process. Pesticides are usually used in modern agriculture for pest controlling because of the productivity benefits they provide. However, exposure to pesticides is harmful to human health and our environment [1]. Animals and Plants going from advantageous soil microorganisms, It is possible to damage trees, birds, fish, insects, and other wildlife by pesticides [2]. Furthermore, pesticides have an especially high sensitivity to humans. Decomposition of pesticide derivatives that enter the food chain causes chronic poisoning of humans and mammals [3]. Environmental pollutants such as pesticides The Allium cepa test may be used to validate genotoxicity and cytotoxicity. In genetic toxicology, cytogenetic studies on human lymphocyte culture are used. Several of these tests are used to determine if chemical agents such as pesticides are potentially genotoxic [4]. Allium cepa is a plant species that is thought to be a successful test tool for determining pesticide genotoxicity [59]. The findings of the Allium test, according to Fiskesjo [10], have shown strong approval with results from other test methods, both prokaryotic and eukaryotic organisms exist. The aim of this study is to determine the cytotoxic and genotoxic effects of the most commonly used pesticide in Iraq's Kurdistan province. as well in Dahouk city which is Herbicides Glyphosate $\left(\mathrm{C}_{3} \mathrm{H}_{8} \mathrm{NO}_{5} \mathrm{P}\right)$. 


\section{Material and Methods}

\subsection{Analysis: Germination (percentage), root duration, and seedling weight}

The lengths of the roots are calculated by the bases, which define the ridicule shape. The root lengths of the grown seeds were determined with a ruler after 72 hours. Using a receptive balance, the seedling weight was determined by measuring the seedling weight before and after Glyphosate application.

The proportion of seeds that germinated was calculated using the following equation:

$\mathbf{G}(\%)=\mathrm{GS} / \mathrm{TS} \times 100$

$\mathrm{G}$ stands for germination (percentage), GS for germinated seeds, and TS for total seeds.

\subsection{Preparation of Chromosome, Mitotic Cell Division and Micronucleus in Allium cepa L. Root Tips}

\subsubsection{Test Organism}

Good onion bulbs had their dry outer scales cut. For 2-4 days, the ready bulbs of Allium cepa L. L. were put in $25 \mathrm{~cm} 3$ vials full of tap water.

\subsubsection{Treatment}

Herbicide is a substance that kills plants. As a research drug, glyphosate was included. Glyphosate concentrations of $0.0,0.5,1.0,2.0$, and 4.0 were used to study glyphosate's impact on onion root tips, as well as the placement of onion bulbs directly on the root tips. Onion bulbs were cultivated in a coarse manner in tap water before being moved to a series of pesticide concentrations for a 24 -hour treatment in another situation.

\subsubsection{Colchicine treatment}

Following the Glyphosate treatment, the root tips were cut off, cleaned, and handled for 3 hours with a 0.05 percent colchicine solution. The aim of colchicine using in this research was to define the possible existence of numerical and structural changes in the chromosomal set of meristematic cells discontinue mitosis in prometaphase.

\subsubsection{Fixation}

One-inch of root tips is trimmed, removed, and fixed for 24 hours in a 1:3 Acetic-Ethanol solution at the end of each treatment day. Five root tips from each bulb were cut and selected for the samples.

\subsubsection{Squash preparation}

The root tip was then hydrolyzed in a tube containing $1 \mathrm{~N} \mathrm{HCl}$ for 6 minutes. The root tips will then be stained with two drops of Giemsa stain and left for 20 minutes. The cells were then gently squashed and uniformly spread [11]. The following details should be used on each slide: Just one root and five slides came from each bulb. Cover root tips with a cloth after staining.

\subsubsection{Microscopical Examination}

A light microscope was used to view the slides. At random, chromosome aberrations in mitotic cells were recorded in five fields on each slide. The X40 or X100 focal lenses were used to photograph any slides (oil immersion lens). Divide the number of dividing cells per field by the total number of cells per field and multiply the results by 100 to get the mitotic indices [12]. 


\subsubsection{Statistical Analysis}

After a few iterations of manual data analysis, the remainder of the computational work was completed using graph pad prism 5.0 program. The treatments were assigned in a completely random sequence (C. R. D). The logical formula was as follows:

$$
y_{i j}=\mu+\mathrm{t}_{\mathrm{i}}+\mathrm{e}_{i j}
$$

Where: $y_{i j}=$ value of $j(\mathrm{j}=1,2,3,4 . \mathrm{r})$ observation of $i$ th $(i=1,2,3,4, . . \mathrm{t})$ treatment

$\mu$ : is the general mean of the population (y..)

$\mathrm{t}_{\mathrm{i}}=$ is ${ }_{\text {the }}$ effect of $i$ th treatment.

$\mathrm{e}_{i j}=$ Experimental Randomized Error.

Then the significant of $(\mathrm{F})$, values from ANOVA tables were tested at $\mathrm{P}<0.05$ and $\mathrm{P}<0.01$. The significance difference between the different treatments in the experiments and their control were determined by using least Significant Differences test (L.S.D).

\section{Results and Discussion}

\subsection{Glyphosate's Effects on A. cepa germination, root volume, and seed weight.}

Table 1 shows the effects of various Glyphosate doses on A. cepa germination proportion, root length, and seed weight (Table 2). (See Figure 1) These tables clearly demonstrated that Glyphosate has a detrimental effect on seed germination. The percentage of Glyphosate-treated seeds that germinated was significantly smaller in the experimental community than in the control group.

Since glyphosate injection, the length and weight of the seeds was significantly decreased. The control category had the longest root length and the heaviest seedling weight after 72 days. Seeds given a $0.4 \mathrm{ml} / \mathrm{L}$ dose of Glyphosate had the shortest root length and the smallest seedling weight. The total seedling weight in the test group rose by around 5.3 grams.

As comparison to their initial weights at $0.5,1.0,2.0$, and $4.0 \mathrm{ml} / \mathrm{L}$ Glyphosate levels, the final weights of the seeds in the treatment groups decreased by about 2.6, 1.5, 0.7, and $0.4 \mathrm{~g}$, respectively. The final calculation after 72 hours showed that the control protocol measured $12.3 \mathrm{~cm}$ with significant variances, compared to $2.4 \mathrm{~cm}$ for the $2 \mathrm{ml} / \mathrm{L}$ treatment.

As comparison to their initial weights at $0.5,1.0,2.0$, and $4.0 \mathrm{ml} / \mathrm{L}$ Glyphosate levels, the final weights of the seeds in the treatment groups decreased by about 2.6, 1.5, 0.7, and $0.4 \mathrm{~g}$, respectively. The final calculation after 72 hours showed that the control protocol measured $12.3 \mathrm{~cm}$ with significant variances, compared to $2.4 \mathrm{~cm}$ for the $2 \mathrm{ml} / \mathrm{L}$ treatment.

In a similar article, Mclaren and Don [13] looked at Glyphosate's impact on barley crops. In the lab, barley crops treated with glyphosate had lower germination rates. According to Klingman and Murray [14], when herbicides including glyphosate and paraquat were present, the proportion of turf grass seeds that germinated was restricted. Pline et al. [15] looked at the functional and morphological aspects of the human body. 
Table 1: Effects of various doses of Glyphosate on the germination percentage, root length and seed weight of A. cepa

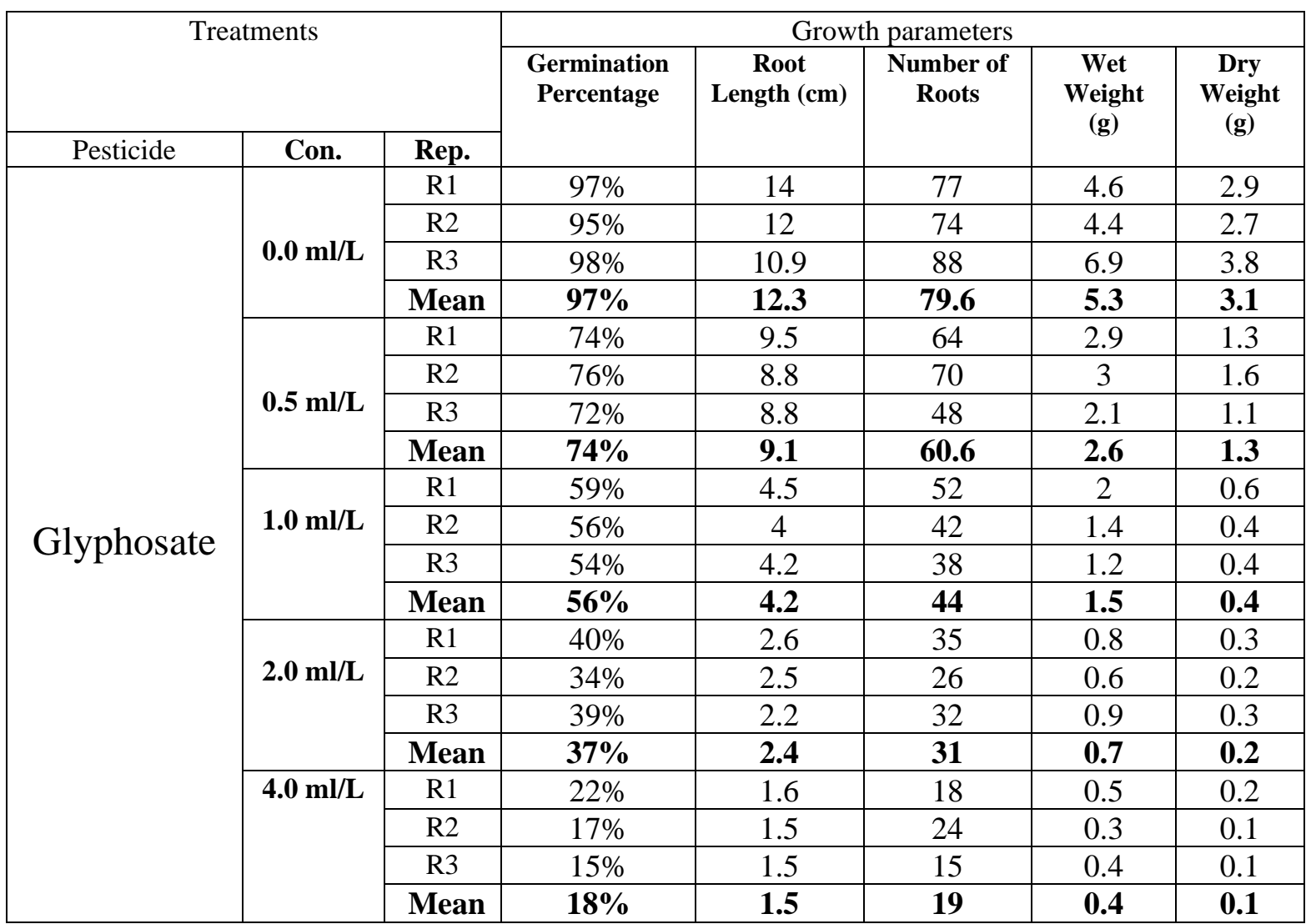



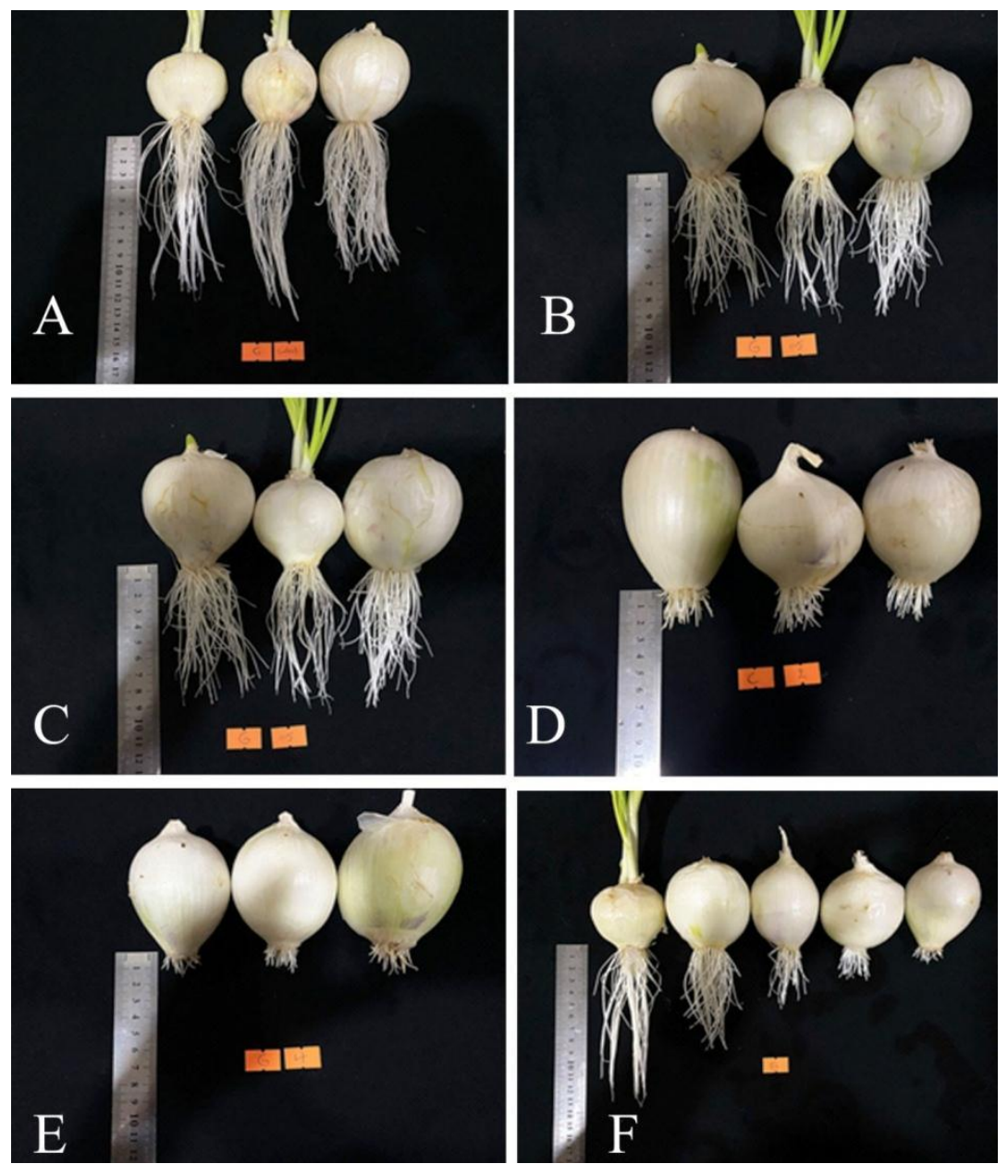

Figure 1: Effect of Glyphosate on root length at various doses: (A) 0.0ml/1 control, (B) $0.5 \mathrm{ml} / 1$ Glyphosate, (C) $1.0 \mathrm{ml} / 1$ Glyphosate, (D) $2.0 \mathrm{ml} / 1$ Glyphosate, (E) $4.0 \mathrm{ml} / 1$ of Glyphosate. 


\subsection{Glyphosate's impact on the mitotic index and cell division of root tips cells of Allium cepa L.}

Figure 2 depicts the stages of mitosis in onion root tip cells. Glyphosate's Effect on (Allium cepa L.) (Table 2 ). The results of the experiment revealed that the occurrence of different mitotic phases and the mitotic index is negatively affected. In contrast to control, inhibition was dose based, and when Glyphosate doses were raised, the inhibition improved significantly (P0.01).

The proportion of mitotic index in the control group was $7.93 \%$, although it was 2.82 percent in the $4.0 \mathrm{ml}$ /L group. For all living species, the mitotic index is an appropriate indicator of cytotoxicity [16]. The reduced rate of mitotic index may be used to assess the degree of cytotoxicity. As compared to control, Glyphosate reduced the mitotic index at all doses and treatment times in this sample. These findings were consistent with several other studies on Allium cepa using the fungicide raxil by Fisun and Rasgele [17].

In a dose-dependent way, the mitotic index decreased. Across all therapy times, the highest dose of blitox decreased mitotic activity rather than most utilized levels. As a result, this knowledge is in line with the results of other scholars. Rank et al [18] investigated the potential genotoxic consequences of Glyphosate isopropyl amine salt in A. cepa.

Table 2: Glyphosate's impact on the mitotic index and cell division of root tips cells of Allium cepa $\mathrm{L}$.

\begin{tabular}{|c|c|c|c|c|c|c|c|}
\hline $\begin{array}{c}\text { Treatments } \\
\text { g/L }\end{array}$ & $\begin{array}{l}\text { no of } \\
\text { examined } \\
\text { cells }\end{array}$ & Prophase & Metaphase & Anaphase & Telophase & $\begin{array}{l}\text { Total } \\
\text { Mitosis }\end{array}$ & $\begin{array}{l}\text { Mitotic } \\
\text { index }\end{array}$ \\
\hline $0.0 \mathrm{ml} / \mathrm{L}$ & 1411.0 & 41.0 & 26.0 & 20.0 & 25.0 & 112.0 & $7.93 \%$ \\
\hline $0.5 \mathrm{ml} / \mathrm{L}$ & 1382.0 & 25.0 & 19.0 & 18.0 & 23.0 & 85.0 & $6.15 \%$ \\
\hline $1.0 \mathrm{ml} / \mathrm{L}$ & 1445.0 & 24.0 & 13.0 & 12.0 & 18.0 & 67.0 & $4.63 \%$ \\
\hline $2.0 \mathrm{ml} / \mathrm{L}$ & 1224.0 & 17.0 & 10.0 & 9.0 & 12.0 & 48.0 & $3.92 \%$ \\
\hline $4.0 \mathrm{ml} / \mathrm{L}$ & 1096.0 & 12.0 & 4.0 & 6.0 & 9.0 & 31.0 & $2.82 \%$ \\
\hline
\end{tabular}

\subsection{The Effects of Glyphosate on chromosomal aberrations and formations of Micronucleus in Allium cepa}

The effects of different Glyphosate treatments on chromosome aberration in A. cepa root tip cells are addressed in this article (Table 3). After 24 hours of therapy, glyphosate caused a wide range of cytotoxic symptoms, including ten different types of chromosomal aberrations (anaphase bridges, micronucleus, star anaphase, vagrant chromosomes, chromatid gaps, fragmented chromosomes, binucleate cells, ring chromosomes and multipolar anaphase).

There was a substantial increase in the total amount of chromosomal anomalies when Glyphosate doses increased, which was dose based. In cells treated with Glyphosate at $4.0 \mathrm{ml} / \mathrm{L}$, the average number of abnormalities increased from 9 in untreated cells to 405 in treated cells.

The most common abnormality was the formation of anaphase bridges, which accounted for 169 cases, followed by the formation of a vagrant chromosome, which accounted for 157 cases, and the formation of multipolarity, which accounted for 19 cases.

In all scored characteristics, there were significant statistical differences in the abbreviation values compared to the control (p0.001). Although multipolarity formations improved as dose concentration increased, these differences were not statistically significant. At all doses and treatment periods, glyphosate significantly reduced the number of abnormal cells in mitotic cell divisions compared to control. Certain fungicides have been shown to trigger chromosomal defects in plants by several researchers [19]. 
These findings affirm the current study's findings that Glyphosate induces a variety of chromosomal aberrations, and that the greater the dosage, the more chromosomal aberrations. By causing chromosomal aberrations in Allium cepa L, such as anaphase bridges, micronucleus, star anaphase, vagrant chromosomes, chromatid gaps, damaged chromosomes, binucleate cells, ring chromosomes, and multipolar anaphase, we might be able to demonstrate Glyphosate's strong toxicity. Krüger [20] observed a significant increase in the amount of micronuclei in A. cepa roots subjected to Glyphosate at concentrations varying from 1 to 201 1-1. Several authors examined A. cepa with solutions of different chemical compounds with cytotoxic potential and found abnormalities close to those found in this study [21]. The presence of the discovered aberrations [22]confirms glyphosate's biocidal impact. To summarize, these chromosomal modifications indicate that Glyphosate has a significant effect on genetic content, suggesting that it is genotoxic [23].

Table 3: chromosomal aberrations and formations of Micronucleus in Allium cepa L. root tip cells exposed to different concentration of Glyphosate.

\begin{tabular}{lccccc}
\hline Type of abnormality & \multicolumn{4}{c}{ Treatments } \\
\cline { 2 - 6 } & $0.0 \mathrm{ml} / \mathrm{L}$ & $0.5 \mathrm{ml} / \mathrm{L}$ & $1.0 \mathrm{ml} / \mathrm{L}$ & $2.0 \mathrm{ml} / \mathrm{L}$ & $4.0 \mathrm{ml} / \mathrm{L}$ \\
Anaphase Bridges & 4 & 16 & 21 & 45 & 83 \\
Micronucleus & 1 & 10 & 18 & 27 & 39 \\
Binucleated cells & 0 & 9 & 17 & 22 & 31 \\
multipolarity & 0 & 0 & 2 & 4 & 13 \\
Fragment chromosome & 2 & 11 & 20 & 35 & 70 \\
vagrant chromosome & 1 & 14 & 24 & 38 & 80 \\
Chromatid gaps & 0 & 8 & 17 & 23 & 41 \\
Star anaphase & 0 & 2 & 8 & 16 & 29 \\
Ring chromosome & 1 & 13 & 14 & 22 & 32 \\
Total Abnormality & 9 & 83 & 141 & 232 & 405 \\
\hline
\end{tabular}

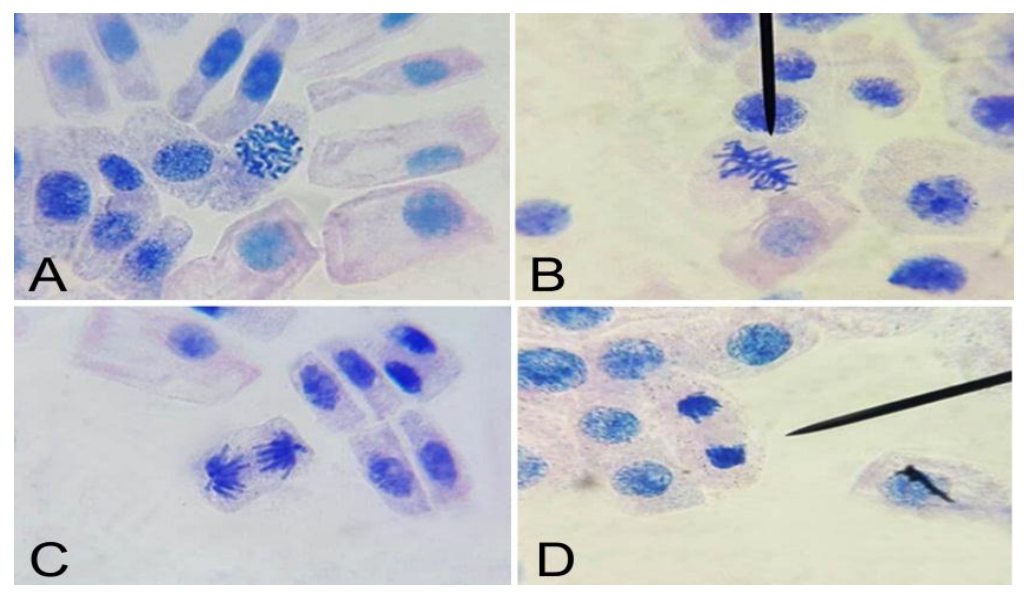

Figure 2: Normal Stages of Mitosis in the Root Tip Cells of Onion (Allium cepa L.): A:Prophase, B: Metaphase, C: Anaphase, D: Telophase. 


\section{BioChemMed}

Technium BioChemMed Vol. 2, Issue 1 pp.131-140 (2021)

ISSN: $2734-7990$
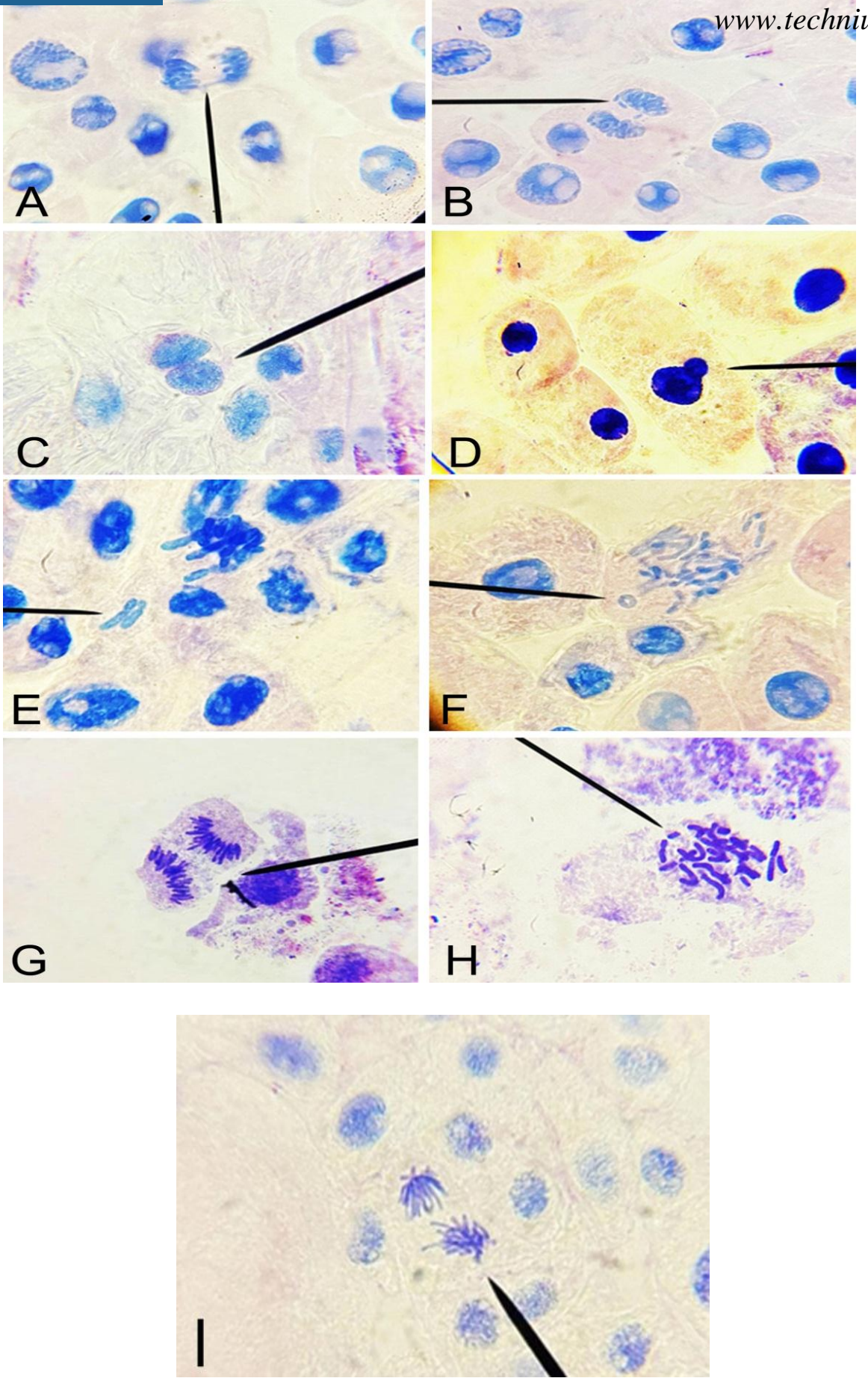

Figure 3: chromosome Abnormality in the Root Tip Cells of Allium cepa L. treated with Glyphosate.: A- Anaphase Bridge, B-Chromatid gap, C- Binucleated cell, D Micronuclei in interphase cell, E- Vagrant chromosome, F- Ring chromosome, G- Multipolarity, H- Fragment chromosome, I- Star-anaphase. 


\section{Conclusion}

According to the results, Glyphosate lowers Allium cepa seed germination and cell mitotic index due to its cytotoxic conduct. Glyphosate triggered chromosomal abnormalities during mitotic cell division. It was discovered that the percentage of mitotic deviations and the mitotic index had a long-term relationship. Glyphosate may be called a plant mutagenic agent based on these results. As a consequence, this fungicide's use in agricultural fields should be tightly controlled.

\section{Reference}

1. Pratte-Santos, R., et al., Evaluation mutagenic potential of pesticides through bioassays with Allium cepa. World Journal of Cell Biology and Genetics, 2015. 2(1): p. 5-10.

2. Sanders, H.O., Toxicity of pesticides to the crustacean Gammarus lacustris. 1969, US Fish and Wildlife Service.

3. Metin, N., et al., Pesticide usage and its effects on the environment in thrace region. The Journal of Environmental Protection and Ecology, 2003. 4: p. 328-333.

4. Ibrulj, S., S. Haverić, and A. Haverić, Complementarity of standard cytogenetic assays. Bosnian journal of basic medical sciences, 2008. 8(1): p. 34.

5. Asita, A.O. and L. Matebesi, Genotoxicity of hormoban and seven other pesticides to onion root tip meristematic cells. African Journal of Biotechnology, 2010. 9(27): p. 4225-4232.

6. Bolle, P., et al., Clastogenicity of atrazine assessed with the Allium cepa test. Environmental and molecular mutagenesis, 2004. 43(2): p. 137-141.

7. Chauhan, L., et al., Diuron-induced cytological and ultrastructural alterations in the root meristem cells ofAllium cepa. Pesticide Biochemistry and Physiology, 1998. 62(3): p. 152-163.

8. Fernandes, T.C., D.E.C. Mazzeo, and M.A. Marin-Morales, Mechanism of micronuclei formation in polyploidizated cells of Allium cepa exposed to trifluralin herbicide. Pesticide Biochemistry and Physiology, 2007. 88(3): p. 252-259.

9. Yüzbaşioğlu, D., F. Ünal, and C. Sancak, Genotoxic effects of herbicide Illoxan (Diclofop-Methyl) on Allium cepa L. Turkish Journal of Biology, 2009. 33(4): p. 283-290.

10. Fiskesjö, G., The Allium test as a standard in environmental monitoring. Hereditas, 1985. 102(1): p. 99-112.

11. Sharma, A. and A. Sharma, Chromosome techniques: theory and practice. 2014: ButterworthHeinemann.

12. Onyemaobi, O., G. Williams, and K. Adekoya, Cytogenetic effects of two food preservatives, Sodium Metabisulphate and Sodium Benzoate on root tips of Allium cepa Linn. 2012.

13. Powell, A., et al., Towards the future in seed production, evaluation and improvement. Seed Science and Technology, 2005. 33(2): p. 265-281.

14. Klingman, D.L. and J. Murray, Germination of seeds of turfgrasses as affected by glyphosate and paraquat. Weed science, 1976: p. 191-193.

15. Pline, W.A., et al., Physiological and morphological response of glyphosate-resistant and nonglyphosate-resistant cotton seedlings to root-absorbed glyphosate. Pesticide Biochemistry and Physiology, 2002. 73(1): p. 48-58. 
16. Smaka-Kincl, V., et al., The evaluation of waste, surface and ground water quality using the Allium test procedure. Mutation Research/Genetic Toxicology, 1996. 368(3-4): p. 171-179.

17. Fisun, K. and P.G. Rasgele, Genotoxic effects of raxil on root tips and anthers of Allium cepa L. Caryologia, 2009. 62(1): p. 1-9.

18. Rank, J., et al., Genotoxicity testing of the herbicide Roundup and its active ingredient glyphosate isopropylamine using the mouse bone marrow micronucleus test, Salmonella mutagenicity test, and Allium anaphase-telophase test. Mutation Research/Genetic Toxicology, 1993. 300(1): p. 2936.

19. Shukla, R., Chromotoxic effects of one fungicide (Dithane M-45) and two insecticides (Aldrex-30 and Metacid-50). Cytologia, 1994. 59(4): p. 419-422.

20. Krüger, R.A., Análise da toxicidade e da genotoxicidade de agrotóxicos utilizados na agricultura utilizando bioensaios com Allium cepa. Novo Hamburgo Dissertação de Mestrado em Qualidade Ambiental-Feevale, 2009.

21. Prajitha, V. and J. Thoppil, Genotoxic and antigenotoxic potential of the aqueous leaf extracts of Amaranthus spinosus Linn. using Allium cepa assay. South African Journal of Botany, 2016. 102: p. 18-25.

22. Van Bruggen, A., et al., Environmental and health effects of the herbicide glyphosate. Science of the Total Environment, 2018. 616: p. 255-268.

23. da Silva, T.F., E.A. Barp, and N. Armiliato, Avaliação da toxicidade celular do glifosato sobre as gônadas de Danio rerio (Cyprinidae). Saúde e meio ambiente: revista interdisciplinar, 2017. 6(1): p. 85-95. 